\title{
Solid-State Fluorescence Enhancement of Bromine-Substituted Trans-Enaminone Derivatives
}

\author{
Hua Li $\mathbf{L}^{\mathrm{a}, \mathrm{b}}$ (1) \\ Haiyang Shu $u^{\mathrm{a}, \mathrm{b}}(\mathbb{0}$

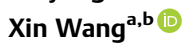 \\ Xiaofu Wu ${ }^{a} \odot$ \\ Hongkun Tian ${ }^{\mathrm{a}, \mathrm{b}}$ (]) \\ Hui Tong ${ }^{* a, b}($ ) \\ Lixiang Wang*a,b (D) \\ ${ }^{\text {a }}$ State Key Laboratory of Polymer Physics and Chemistry, Changchun Institute of \\ Applied Chemistry, Chinese Academy of Sciences, Changchun 130022, China \\ b University of Science and Technology of China, Hefei 230026, China \\ chemtonghui@ciac.ac.cn; lixiang@ciac.ac.cn.
}

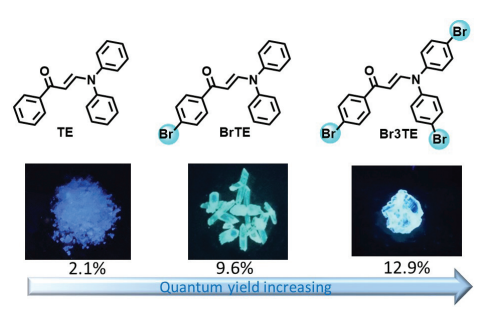

applications of those molecules in organic electronics and biosensors. ${ }^{1}$ Notoriously, the emissions of most organic fluorophores are quenched in the solid state and this seriously limits their applications. ${ }^{2}$ To avoid the aggregation-caused quenching, a large number of conjugated or nonconjugated molecules with aggregation-induced emission (AIE) property have been studied since the first AIE molecule was proposed by Tang et al in $2001 .^{3}$ Considering the restriction of the intramolecular motion mechanism of the AIE materials, the molecular packing mode can exert an important influence on their emissive properties. ${ }^{4}$ This may be tuned by weak interactions, such as hydrogen bonding, ${ }^{5}$ $\pi-\pi$ interaction, ${ }^{6}$ and van der Waals interaction. ${ }^{7}$ Investigating the packing modes and intermolecular interactions in crystal structures is therefore of great interest to help designing highly luminescent molecules in solid states. ${ }^{8}$

Halogen bonding is a strong and directional interaction between a polarized halogen atom and a Lewis base as officially defined by IUPAC in 2013. ${ }^{9}$ This noncovalent interaction is similar to hydrogen bonding ${ }^{10}$ and in recent years, due to its higher directionality and broader tunability, it has been established as a powerful interaction to use for self-assembly in condensed phases and for application in biological systems. ${ }^{11}$ Halogen-bonding interactions have shown superior anion affinities and contrasting selectivities in the anion recognition and sensing process due to their electron-deficient and hydrophobic nature. ${ }^{12}$ Furthermore, investigations on the application of halogen bonding donor systems as catalysts in organic synthesis have been also highlighted. ${ }^{13}$ Although the importance of halogen bonding has been recognized in numerous applications, the use of halogen bonding to tune luminescence properties in the field of organic luminogens has long been overlooked.

In recent years, halogen atoms $(\mathrm{Br}, \mathrm{I})$ have been used to design highly efficient room-temperature phosphorescent materials due to their heavy atom effect which strengthens the efficiency of the intersystem crossing process between the singlet and triplet states. ${ }^{14}$ Moreover, the formation of
Research studies on organic fluorophores with high emission in the solid state are appealing due to the potential 
halogen bonding in solid states induced the rigidification effect, which can reduce vibrational relaxations of triplets, resulting in strong phosphorescence emission. ${ }^{15}$ Halogen bonding is also an effective strategy for tuning the solidstate fluorescence properties such as emission color, lifetime, and fluorescence intensity. ${ }^{16}$ In a recent work, we have reported a planar bromine-substituted cis-enaminone fluorophore with AIE property. ${ }^{17}$ Compared with its analogue without bromine, it exhibits a much stronger solid-state fluorescence emission because the formation of intermolecular $\mathrm{Br}$...Br halogen bonding suppresses molecular motions more efficiently.

To further study the effect of halogen bonding on fluorescence enhancement, in this work we designed and synthesized three bromine-substituted trans-enaminone derivatives: (E)-3-(diphenylamino)-1-phenylprop-2-en-1one (TE), (E)-1-(4-bromophenyl)-3-(diphenylamino)prop2-en-1-one (BrTE), and (E)-3-(bis(4-bromophenyl)amino)1-(4-bromophenyl)prop-2-en-1-one (Br3TE) (Figure 1). All the three trans-enaminone derivatives exhibit AIE properties. Interestingly, two types of crystals (BrTE-G and BrTE-B) of BrTE with different fluorescence properties were obtained. The crystal BrTE-G containing $\mathrm{Br} . . . \pi$ intermolecular interactions exhibits a nearly sevenfold higher fluorescence quantumyield (9.6\%) compared to BrTE-B, the crystal without halogen bonding. Additionally, increasing the number of $\mathrm{Br}$ substituents leads to an even higher fluorescence quantum yield of Br3TE of up to $12.5 \%$, whereas the fluorescence quantum yield of TE is only $2.1 \%$.

\section{Results and Discussion}

The preparation procedures of TE, BrTE, and Br3TE are summarized in Scheme 1. The alkynol intermediate was facilely synthesized via a Grignard reaction between ethynylmagnesium bromide and benzaldehyde in dry tetrahydrofuran (THF) at room temperature, and then oxidized by 2iodobenzoic acid (IBX) in ethyl acetate at $90{ }^{\circ} \mathrm{C}$ to obtain alkynone. An aza-Michael addition between alkynone and a secondary amine in methanol at room temperature produced TE, BrTE, and Br3TE in satisfactory yields. ${ }^{18}$ Their chemical structures were fully characterized by ${ }^{1} \mathrm{H}$ and ${ }^{13} \mathrm{C}$ NMR spectroscopy, FT-IR, mass spectrometry, and elemental

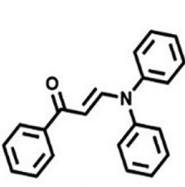

TE

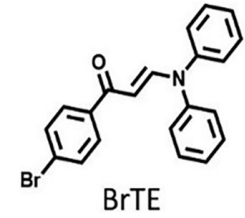

BrTE

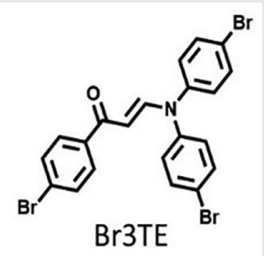

Br3TE
Figure 1 Structures of three trans-enaminone derivatives TE, BrTE, and Br3TE.

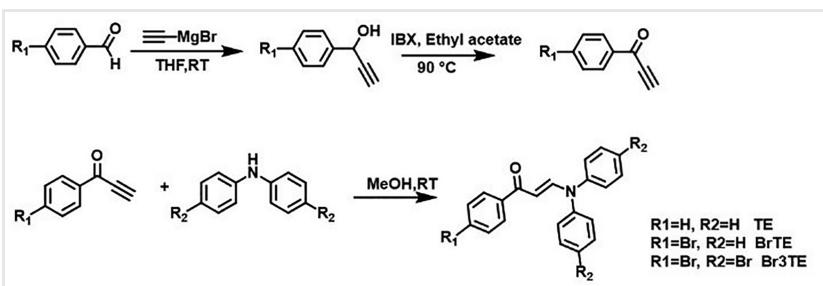

Scheme 1 Synthetic routes of three trans-enaminone derivatives TE, $\mathrm{BrTE}$, and $\mathrm{Br} 3 \mathrm{TE}$.

analysis. The trans-conformations of the enaminone derivatives were confirmed by ${ }^{1} \mathrm{H}$ NMR spectra where the doublet at 6.03 ppm with a coupling constant of $12.8 \mathrm{~Hz}$ (Figures S12S14) corresponds to the vinyl proton adjacent to the $\alpha$-keto. All the compounds have good solubility in common organic solvents such as $n$-hexane (Hex), chloroform $\left(\mathrm{CHCl}_{3}\right), \mathrm{THF}$, and dimethylformamide (DMF). In $\mathrm{CHCl}_{3}$ solution, $\mathrm{TE}$ shows an absorption maximum at $366 \mathrm{~nm}$, while the absorption maxima of BrTE and Br3TE slightly red-shift to 370 and $369 \mathrm{~nm}$, respectively (Figure S1 and Table S1). The three compounds show weak emission peaks at around $516 \mathrm{~nm}$ in $\mathrm{CHCl}_{3}$. All of their emission spectra are sensitive to solvent polarity, and the emission peaks show bathochromic shifts of more than $60 \mathrm{~nm}$ with the increase in solvent polarity, indicating the existence of effective intramolecular charge transfer (Figure S2 and Table S1).

In order to study the luminescence of aggregates, typical AIE experiments were performed in $\mathrm{DMF} / \mathrm{H}_{2} \mathrm{O}$ mixtures with different water fractions $\left(f_{\mathrm{w}}\right)$. As shown in Figure 2, the emission of BrTE in DMF is rather weak. However, significantly enhanced emission is observed when the $f_{\mathrm{w}}$ exceeds $70 \%$. Careful inspection of the photoluminescence spectra of BrTE reveals that the emission peak blue-shifts from 519 to $490 \mathrm{~nm}$ with the increase in $f_{\mathrm{w}}$, which suggests the formation of aggregates with the restriction of the intramolecular charge transfer process. ${ }^{19}$ Compared with pure DMF solution, the emission intensity of BrTE increases by about 28 -fold in $\mathrm{DMF} / \mathrm{H}_{2} \mathrm{O}$ mixtures $\left(f_{\mathrm{w}}\right.$ of $90 \%$ ). Similar emission enhancements are also observed for TE and Br3TE

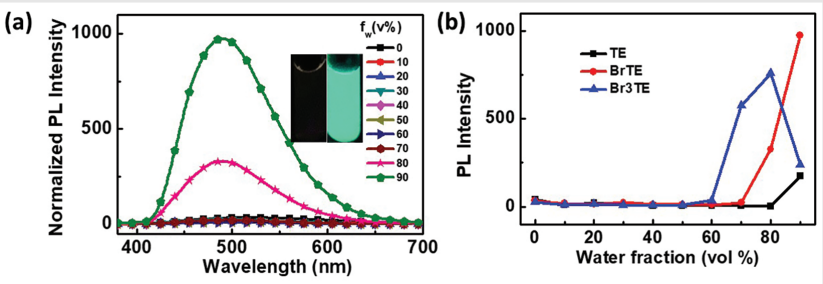

Figure 2 Photoluminescence (PL) spectra of BrTE (a) in the mixtures of DMF and water $\left(10 \mu \mathrm{M}, \lambda_{\mathrm{ex}}=360 \mathrm{~nm}\right.$, water contents $\left.0-90 \%\right)$. Inset: photographs in DMF and DMF/ $\mathrm{H}_{2} \mathrm{O}$ (1:9) mixture under a 365-nm lamp. (b) Plots of $\mathrm{PL}$ intensity versus the composition of $\mathrm{DMF} / \mathrm{H}_{2} \mathrm{O}$ mixtures of $\mathrm{TE}$, BrTE, and $\mathrm{Br} 3 \mathrm{TE}$. 
(a)

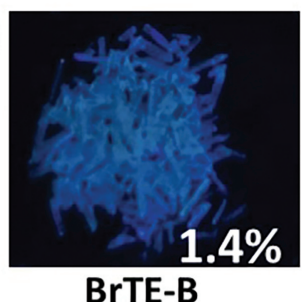

(c)

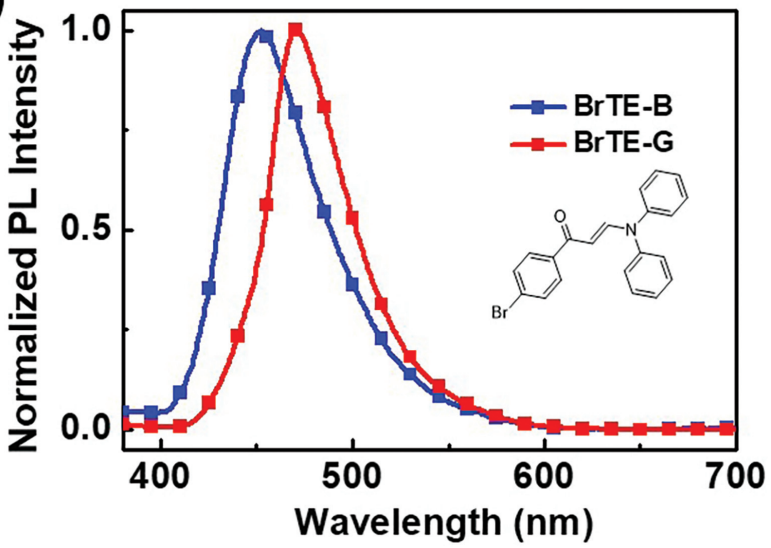

Figure 3 Photographic images of polymorphs BrTE-B (a) and BrTE-G (b); (c) fluorescence emission spectra of BrTE-B and BrTE-G $\left(\lambda_{\mathrm{ex}}=360 \mathrm{~nm}\right)$.

(Figures 1b and S3). Clearly, the three trans-enaminone molecules possess AIE properties.

To gain further insight into the influence of bromine atoms on solid-state luminescence, the crystals of all three compounds were cultivated by slow vaporization of the corresponding compound solutions. To our surprise, two distinct types of BrTE crystals are obtained, the needle-like crystals with very weak deep-blue emission (BrTE-B) are obtained from methanol solution (Figure $3 a$ ) and the rodlike crystals with bright sky-blue emission (BrTE-G) from hexane solutions (Figure $3 \mathrm{~b}$ ). By the investigation of their photoluminescence (PL) spectra as shown in Figure 3c, the emission of BrTE-B shows a peak at $452 \mathrm{~nm}$ with a fullwidth at half-maximum (FWHM) of $59 \mathrm{~nm}$, while BrTE-G exhibits red-shifted emission with a peak at $470 \mathrm{~nm}$ and a smaller FWHM of $47 \mathrm{~nm}$, suggesting that the two crystals may have different molecular packing structures. Unfortu- nately, only polycrystals of TE and Br3TE rather than single crystals were obtained (Figure S5). The emission peaks of TE and Br3TE in crystals are found at $466 \mathrm{~nm}$ and $460 \mathrm{~nm}$, respectively. The fluorescence emissions of all these crystals are confirmed by their luminescence lifetimes in nanoseconds (Table 1, Figure S7) and red-shifted phosphorescence emissions at low temperature (Figures S8 and S9). It is worth noting that the absolute fluorescence quantum yield of BrTE-G (9.6\%) is nearly sevenfold than that of BrTE-B $(1.4 \%)$. The fluorescence quantum yield of the crystal of $\mathbf{T E}$ is 2.1\%, which is comparable to that of BrTE-B but much lower than that of BrTE-G. However, the crystal of Br3TE has the highest fluorescence quantum yield of $12.5 \%$ among the four crystals. Unlike the conventional heavy-atom quenching fluorescence, the introduction of bromine atoms into transenaminone derivatives could enhance fluorescence quantum yields in solid states.

The single-crystal X-ray diffraction data of BrTE-B and BrTE-G were further analyzed. As shown in Figure 4, BrTEB and BrTE-G adopt similar distorted conformations, in which the benzene ring $B$ is almost perpendicular to the conjugated molecular backbone. For BrTE-B, the distortion angle of the conjugated backbone $\mathrm{C}(\mathrm{O})-\mathrm{C}=\mathrm{C}-\mathrm{N}$ is $177.80^{\circ}$. The dihedral angles between the conjugated backbone and the benzene rings $A$ and $C$ are $24.27^{\circ}$ and $37.47^{\circ}$, respectively. However, BrTE-G adopts a relatively planar conformation since the conjugated backbone $\mathrm{C}(\mathrm{O})-\mathrm{C}=\mathrm{C}-$ $\mathrm{N}$ is nearly planar with a distortion angle of $179.96^{\circ}$ and the dihedral angles between the conjugated backbone $\mathrm{C}$ (O) $-\mathrm{C}=\mathrm{C}-\mathrm{N}$ and the benzene rings $\mathrm{A}$ and $\mathrm{C}$ are $7.13^{\circ}$ and $9.05^{\circ}$, respectively, which are much smaller than those in BrTE-B. A less twisted molecular conformation of BrTE-G could lead to the red-shifted emission. Both of BrTE-B and BrTE-G dimers assume antiparallel stacking between two bromine-substituted benzene rings with a $\pi$... $\pi$ distance of 3.29 and $3.51 \AA$, respectively. In the BrTE-G dimer, $\mathrm{Br} . . . \pi$ interaction between the two adjacent molecules with a distance of $3.36 \AA$ is formed, which allows the adjacent two molecules to lock together more tightly. Besides the $\mathrm{Br} . . \pi$ and $\pi . . . \pi$ interactions, more short intermolecular interactions of the crystal BrTE-G, including C-H...O (2.64, $2.52 \AA), \quad$ C-O...C (3.21 $\AA$ ), and C-H...C $(2.78,2.77 \AA)$ (Figure $5 \mathrm{~b}$ ), will enable the molecules to immobilize in a more rigidified environment. In contrast, in the crystal

Table 1 Summary of photophysical properties of TE, BrTE-B, BrTE-G, and Br3TE in crystal states at $298 \mathrm{~K}$

\begin{tabular}{llllll}
\hline Compound & $\lambda_{\mathrm{em}}(\mathrm{nm})$ & $\mathrm{T}(\mathrm{ns})$ & $\Phi_{\mathrm{F}}$ & $k_{\mathrm{r}}\left(10^{8} \mathrm{~s}^{-1}\right)$ & 0.28 \\
TE & 466 & 0.73 & $2.1 \%$ & $k_{\mathrm{nr}}\left(10^{8} \mathrm{~s}^{-1}\right)$ \\
BrTE-B & 452 & 0.67 & $1.4 \%$ & 0.21 & 13.4 \\
BrTE-G & 470 & 1.09 & $9.6 \%$ & 0.88 & 14.7 \\
Br3TE & 460 & 0.91 & $12.5 \%$ & 1.37 & 8.29 \\
\hline
\end{tabular}


(a)

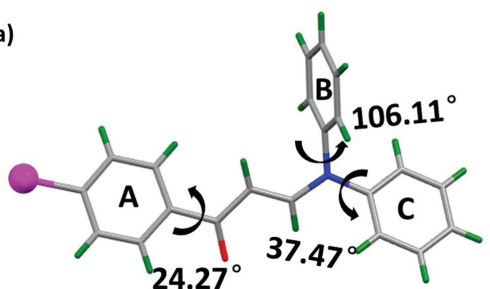

(c)

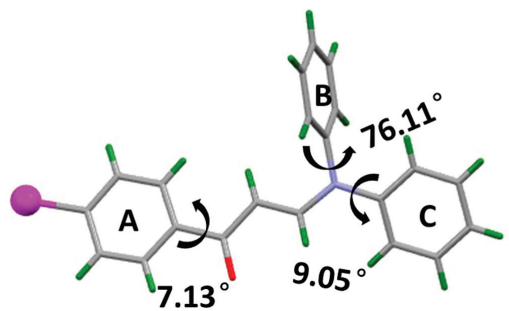

(b)

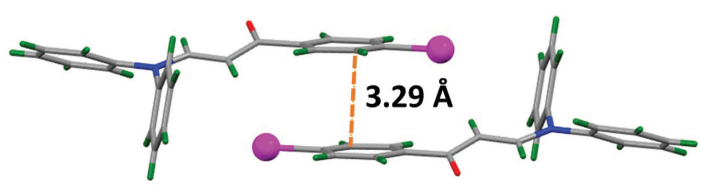

(d)

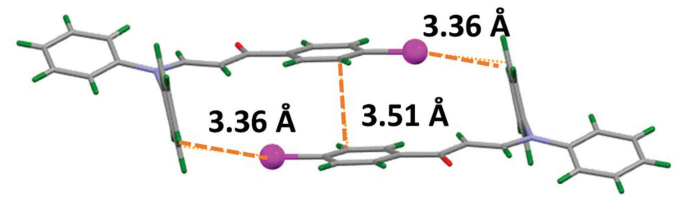

Figure 4 Molecular structure and dimer modes of $\operatorname{BrTE}-\mathbf{B}(a, b)$ and $\operatorname{BrTE}-\mathbf{G}(c, d)$.

BrTE-B, the less intermolecular interactions [C-H... $\pi(2.86$, $2.89 \AA)$ and an additional $\pi . . . \pi(3.33 \AA)$ ] reveal the loose molecular packing (Figure $5 a)$. The smaller single-molecular average volume in the crystal lattice $\left(419.7 \AA^{3}\right)$ and the larger crystal density $\left(1.497 \mathrm{~g} \mathrm{~cm}^{-3}\right)$ of BrTE-G compared to those of BrTE-B (426.9 $\AA^{3}$ and $1.471 \mathrm{~g} \mathrm{~cm}^{-3}$ ) also indicate that BrTE-G adopts a tighter molecular packing mode. According to thermogravimetric analysis (TGA) and differential scanning calorimetry (DSC) curves (Figure S6), both decomposition and melting temperatures of BrTE-G are higher than those of BrTE-B, which is well consistent

(a)
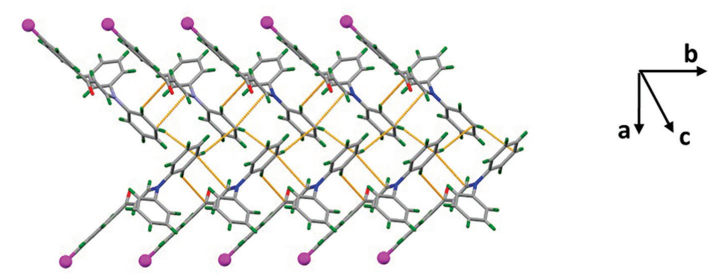

(b)

$$
\begin{aligned}
& \mathrm{C}-\mathrm{H} \cdots \pi: 2.86,2.89 \AA \\
& \pi \cdots \pi: 3.33 \AA
\end{aligned}
$$
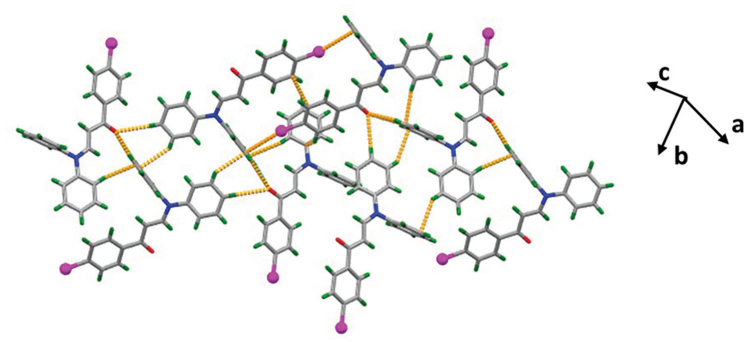

$\mathrm{C}-\mathrm{H} \cdots \mathrm{O}: 2.64,2.52 \AA$ 的 $\mathrm{C}-\mathrm{O} \cdots \mathrm{C}: 3.21 \AA$

$\mathrm{C}-\mathrm{H} \cdots \mathrm{C}: 2.78,2.77 \AA$

Figure 5 Molecular packing in BrTE-B (a) and BrTE-G (b), as viewed perpendicular to the direction in which the dimer is formed. with the more stable crystal structure and stronger intermolecular interactions of BrTE-G. As compared with the crystal BrTE-B, the tighter molecular stacking and more rigidified environment of the crystal BrTE-G suppress the molecular motions more efficiently, leading to significantly enhanced fluorescence quantum yields.

To further reveal the origin of fluorescence enhancement, the radiative $\left(k_{\mathrm{r}}\right)$ and nonradiative decay rates $\left(k_{\mathrm{nr}}\right)$ are estimated by combining the quantum yield $\left[\Phi_{F}=k_{\mathrm{r}}\right.$ ] $\left.\left(k_{\mathrm{r}}+k_{\mathrm{nr}}\right)\right]$ and fluorescence lifetime results $\left[\tau=\left(k_{\mathrm{r}}+\right.\right.$ $\left.k_{\mathrm{nr}}\right)^{-1}$. As shown in Table 1, BrTE-B and TE show similar $k_{\mathrm{r}}$ and $k_{\mathrm{nr}}$. For both of them, rather low $k_{\mathrm{r}}$ values and over high $k_{\mathrm{nr}}$ values lead to similar fluorescence quantum yields of around $2 \%$ because of their loose molecular stacking. Compared with BrTE-B, the $k_{\mathrm{r}}$ value of BrTE-G increases by about fourfold (from $0.21 \times 10^{8}$ to $0.88 \times 10^{8} \mathrm{~s}^{-1}$ ) and the $k_{\text {nr }}$ value nearly reduces to half (from $14.7 \times 10^{8}$ to $8.29 \times 10^{8} \mathrm{~s}^{-1}$ ), which results in the high fluorescence quantum yield of $9.6 \%$, indicating that more compact and rigidified crystal structures induced by $\mathrm{Br} . . . \pi$ halogen bonding and other strong molecular interactions may promote radiative transition but block the nonradiative relaxation efficiently. Compared with BrTE-G, a further increase in the $\boldsymbol{k}_{\mathrm{r}}$ value of the Br3TE crystal leads to a higher fluorescence quantum yield of $12.5 \%$, possibly due to more halogen bonding interactions. Therefore, the solid fluorescence of trans-enaminone can be regulated by adjusting the number of bromine atoms.

Theoretical calculations were carried out on the monomer and dimer derived from the single-crystal structures of BrTE-B and BrTE-G by TD-DFT at the level of the B3LYP/6-31G (d,p) basis set (Figure 6). For both BrTEG and BrTE-B, the HOMOs are primarily localized on the electron-donating diphenylamine groups and enaminone [C $(\mathrm{O})-\mathrm{C}=\mathrm{C}-\mathrm{N}]$ moieties, and the LUMOs are delocalized on the whole conjugated skeletons, suggesting the existence of 
Organic Materials

\section{.}
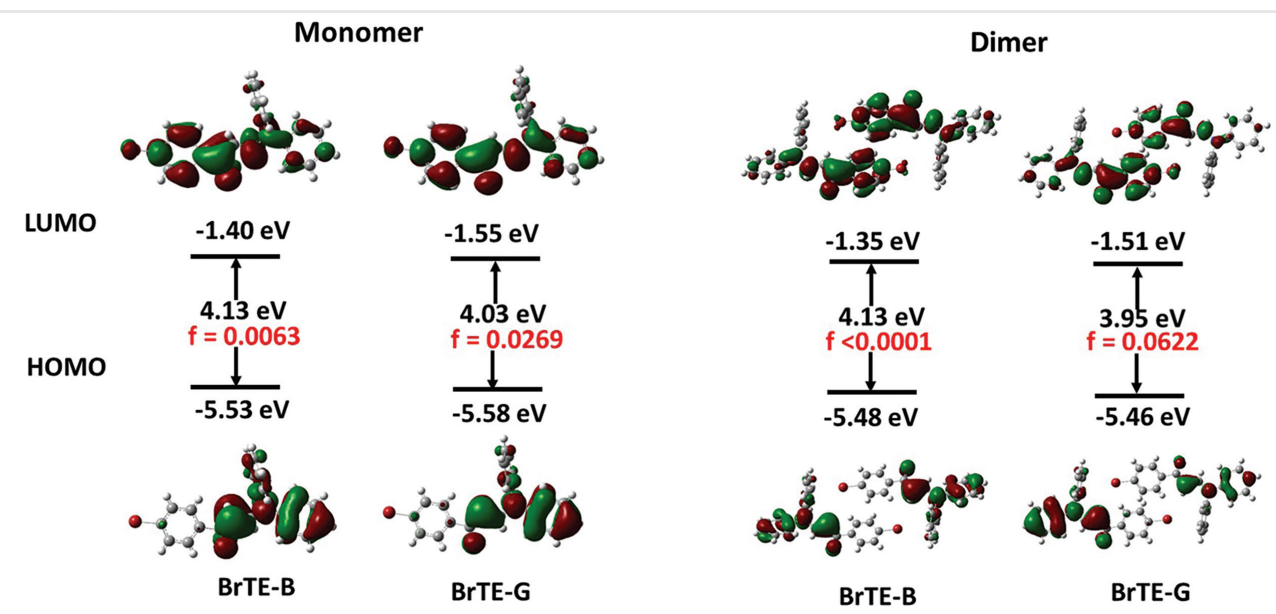

Figure 6 The frontier orbitals and energy levels of the monomers and dimers of BrTE-B and BrTE-G calculated by TD-DFT calculations at the B3LYP/6$31 \mathrm{~g}(\mathrm{~d}, \mathrm{p})$ level.

intramolecular charge transfer. Both the monomers and dimers of BrTE-G exhibit a narrower calculated band gap and a larger oscillator strength than those of BrTE-B, which is in agreement with the red-shifted emission and higher $k_{\mathrm{r}}$ value of the BrTE-G crystal. Note that from the monomer to the dimer, the oscillator strength $(f)$ of BrTE-G $(f=0.0269)$ further increases to 0.0622, while that of BrTE-B $(f=0.0063)$ almost decreases to zero, indicating that the formation of halogen bonding may help to achieve the higher radiative decay rate in crystal states.

We further studied the aggregated state of BrTE-G and BrTE-B using a quantum mechanics and molecular mechanics (QM/MM) approach, ${ }^{20}$ and measured the dihedral angles of BrTE-G and BrTE-B in $S_{1}$ and $S_{0}$ states optimized in the crystal phase (Figures $\mathrm{S} 10$ and S11, and Table 2). From the $S_{0}$ state to the $S_{1}$ state, the brominesubstituted benzene ring against the enaminone moiety in the BrTE-B crystal undergoes a rotational motion with a relatively large dihedral angle change $\left(\Delta\left|S_{1}-S_{0}\right|=14.09^{\circ}\right)$. In contrast, all the dihedral angle changes in the BrTE-G crystal are smaller than $5^{\circ}$. The smaller geometrical modification from the $S_{0}$ to $S_{1}$ state for the BrTE-G crystal reveals that the molecular conformation of BrTE is restricted in a more rigidified environment by halogen bonding and other intermolecular short contacts, which may account for its lower nonradiative decay rate and much stronger solid-state fluorescence as compared with BrTE-B.

\section{Conclusions}

In summary, we have synthesized three AIE-active transenaminone derivatives with and without bromine substituents (TE, BrTE, and Br3TE). Two single crystals (BrTE-B and BrTE-G) of BrTE with different fluorescence properties have been obtained. Notably, BrTE-G with $\mathrm{Br}$... $\pi$ halogen bonding exhibits nearly sevenfold and fivefold higher fluorescence quantum yields compared with BrTE-B and TE, respectively. The tighter molecular stacking and more rigidified environment caused by the intermolecular $\mathrm{Br} . . . \pi$ halogen bonding as well as the multiple stronger intermolecular contacts for the BrTE-G crystal can restrict molecular motions and promote the fluorescence emission process,

Table 2 Selected dihedral angles in their optimized geometric structures for $\mathrm{BrTE}-\mathrm{B}$ and $\mathrm{BrTE}-\mathrm{G}$ calculated in their crystal phase

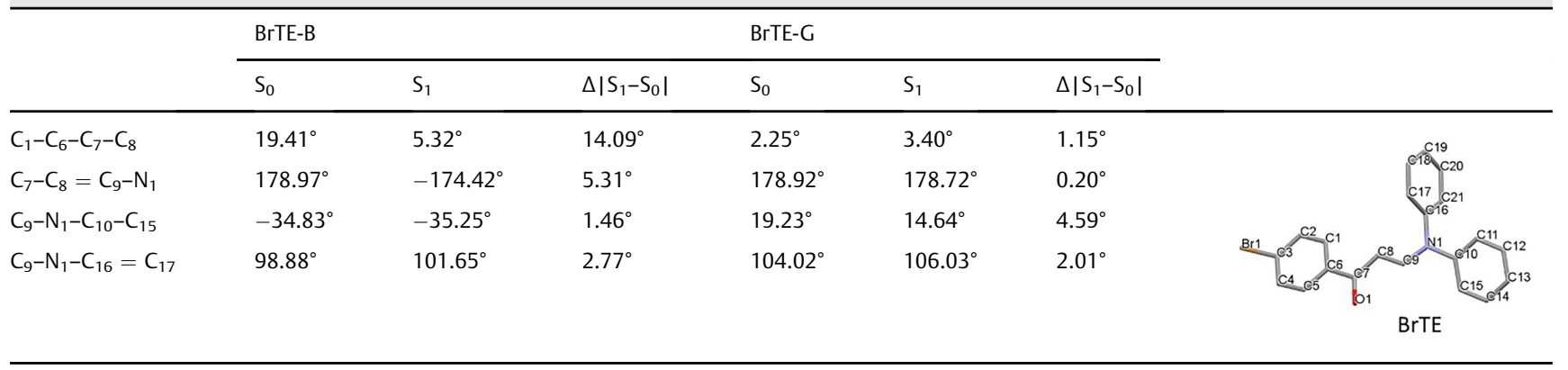


which is responsible for its high fluorescence quantum yield. Moreover, theoretical calculation also demonstrates that the formation of halogen bonding can result in a higher oscillator strength $(f)$ and a smaller geometrical modification in the excited state, which may not only increase the probability of singlet radiative transition but also reduce the nonradiative decay rate, resulting in fluorescence enhancement in the solid states. Additionally, Br3TE with three bromine substituents exhibits an even higher fluorescence quantum yield than BrTE-G, indicating that the increased bromine atoms may be favorable for the formation of halogen bonding and fluorescence emission. We believe that manipulation of halogen bonding is a powerful strategy for designing bright fluorescent molecules in the solid state.

\section{Experimental Section}

\section{Measurements and Characterization}

The ${ }^{1} \mathrm{H}$ NMR spectra were recorded at $400 \mathrm{MHz}$ (Bruker $\mathrm{AV}$ ) or $500 \mathrm{MHz}$ (Bruker $\mathrm{AV}$ ) and the ${ }^{13} \mathrm{C}$ NMR spectra were recorded at 100 or $125 \mathrm{MHz}$ with TMS as the internal standard. All shifts are given in ppm. All coupling constants ( $J$ values) are reported in hertz $(\mathrm{Hz})$. Highresolution mass spectra were obtained by using LTQ Orbitrap Velos Pro. The elemental analysis was performed on a Bio-Rad elemental analysis system. Fourier-transform infrared spectra were obtained on a FT-IR Bruker Vertex 70 spectrometer. The power samples were prepared by adding model compounds and polymers into $\mathrm{KBr}$, and the mixture was ground to a fine powder and pressed to form a disk. UV/Vis absorption spectra were recorded using a Perkin-Elmer Lambda $35 \mathrm{UV} / \mathrm{Vis}$ spectrometer, with a scan rate of $480 \mathrm{~nm} / \mathrm{min}$. Photoluminescence (PL) measurements were conducted utilizing a Hitachi F-7000 spectrophotometer equipped with a $150-\mathrm{W}$ xenon lamp as the excitation source. The PLQYs were measured on an integrating sphere (Hamamatsu Photonics C9920-2). The empty and clean quartz cells (diameter is $15 \mathrm{~mm}$, height is $5 \mathrm{~mm}$ ) were set as the reference sample, and then the solid samples were encapsulated in quartz cells placed in the integral sphere. Each sample was tested three times, and the error was less than $1 \%$. Fluorescence lifetimes were measured with an Edinburgh fluorescence spectrometer (FLSP-980). The lifetime $(\tau)$ of the luminescence was obtained by fitting the decay curve with a multiexponential decay function of

$$
I(t)=\sum A_{i} e^{-t / \pi i}
$$

where $A_{i}$ and $\tau_{i}$ represent the amplitudes and lifetimes of the individual components for multiexponential decay profiles, respectively. The mean lifetime is $\langle\tau\rangle=\Sigma A_{i} \tau_{i}$.
Crystal cultivation: BrTE-B and BrTE-G were cultivated from pure methanol $\left(1 \mathrm{mg} \mathrm{mL}^{-1}\right)$ and hexane $\left(1 \mathrm{mg} \mathrm{mL}^{-1}\right)$ solutions by slow evaporation at $25{ }^{\circ} \mathrm{C}$ for 1 week, respectively. The single-crystal $\mathrm{X}$-ray diffraction experiments were carried out using a Bruker Smart APEX diffractometer with a CCD detector and graphite monochromator, Mo K $\alpha$ radiation $(\lambda=0.71073 \AA)$. The intensity data were recorded with the $\omega$ scan mode. Lorentz polarization factors were made for the intensity data and absorption corrections were performed using the SADABS program. The crystal structure was determined using the SHELXTL program and refined using full matrix least squares. All non-hydrogen atoms were assigned with anisotropic displacement parameters, whereas hydrogen atoms were placed at calculated positions theoretically and included in the final cycles of refinement in a riding model along with the attached carbons.

All calculations were performed with the Gaussian 09 program. The frontier orbitals and energy levels of BrTE-G and BrTE-B in the monomer molecule and dimer are calculated by TD-DFT calculations at the B3LYP/6-31g (d,p) level. The geometry structures for S0 and S1 in the crystalline phase were optimized by using DFT calculations and TD-DFT calculations at the ONIOM (B3LYP/6-31G (d,p): UFF) level.

\section{Materials}

All chemicals and reagents were used as received from commercial sources without further purification. Solvents for chemical synthesis were purified according to the standard procedures.

1-Phenylprop-2-yn-1-ol: a solution of ethynylmagnesium bromide ( $0.5 \mathrm{M}$ in THF, $26 \mathrm{~mL}, 13 \mathrm{mmol}, 1.3$ equiv.) was added at $0{ }^{\circ} \mathrm{C}$ to a solution of the corresponding benzaldehyde $(10 \mathrm{mmol})$ in THF $(20 \mathrm{~mL})$. After the mixture had been stirred for $2 \mathrm{~h}$ at room temperature, a saturated solution of $\mathrm{NH}_{4} \mathrm{Cl}(20 \mathrm{~mL})$ was added to the solution and the THF was evaporated under vacuum. The aqueous phase was extracted three times with ethyl acetate and the organic layers were washed with water and brine and then dried with anhydrous $\mathrm{Na}_{2} \mathrm{SO}_{4}$. After evaporation of the solvent, the resulting crude product was purified by column chromatography (heptane/ethyl acetate $=20 / 1, \mathrm{v} / \mathrm{v})$ to give as yellow solid $(1.0 \mathrm{~g}$, $7.9 \mathrm{mmol}, 79 \%) .{ }^{1} \mathrm{H}$ NMR (400 $\left.\mathrm{MHz}, \mathrm{CDCl}_{3}\right): \delta(\mathrm{ppm})$ $7.55(\mathrm{~m}, 2 \mathrm{H}, \mathrm{Ar}-\mathrm{H}), 7.36(\mathrm{~m}, 3 \mathrm{H}, \mathrm{Ar}-\mathrm{H}), 5.48(\mathrm{~d}$, $J=2.2 \mathrm{~Hz}, 1 \mathrm{H}, \mathrm{CH}), 2.68(\mathrm{~d}, J=2.2 \mathrm{~Hz}, 1 \mathrm{H}, \mathrm{C} \equiv \mathrm{CH}), 2.05$ $(\mathrm{s}, 1 \mathrm{H}, \mathrm{OH}) ;{ }^{13} \mathrm{C}$ NMR $\left(100 \mathrm{MHz}, \mathrm{CDCl}_{3}\right): \delta(\mathrm{ppm}) 140.2$, 128.7, 128.6, 126.7 ( $\left.\mathrm{C}_{\mathrm{Ar}}\right), 83.5,74.8(\mathrm{C} \equiv \mathrm{C}), 64.4(\mathrm{CH})$. 1-Phenylprop-2-yn-1-one: IBX $(2.8 \mathrm{~g}, 10 \mathrm{mmol}$, 2 equiv.) was added in one portion to a solution of 
1-phenylprop-2-yn-1-ol (660 mg, $5 \mathrm{mmol}, 1$ equiv.) in ethyl acetate $(25 \mathrm{~mL})$. The mixture was heated at $90{ }^{\circ} \mathrm{C}$ and stirred overnight. After cooling to room temperature, the mixture was filtered and ethyl acetate was evaporated under vacuum. The resulting crude product was purified by column chromatography (heptane/ethyl acetate $=100 / 1, \mathrm{v} / \mathrm{v}$ ) to give in pure form as a yellow solid (611 mg, $4.7 \mathrm{mmol}, 94 \%) .{ }^{1} \mathrm{H}$ NMR (400 MHz, $\left.\mathrm{CDCl}_{3}\right) \delta(\mathrm{ppm}) 8.1(\mathrm{~m}, 2 \mathrm{H}, \mathrm{Ar}-\mathrm{H}), 7.65(\mathrm{~m}, 1 \mathrm{H}, \mathrm{Ar}-\mathrm{H})$, $7.51(\mathrm{~m}, 2 \mathrm{H}, \mathrm{Ar}-\mathrm{H}), 3.44(\mathrm{~s}, 1 \mathrm{H}, \mathrm{C} \equiv \mathrm{CH}) .{ }^{13} \mathrm{C}$ NMR $\left(100 \mathrm{MHz}, \mathrm{CDCl}_{3}\right): \delta(\mathrm{ppm}) 177.7(\mathrm{C}=0), 136.2,134.5$, 129.7, $128.7\left(\mathrm{C}_{\mathrm{Ar}}\right), 80.7,80.3(\mathrm{C} \equiv \mathrm{C})$.

(E)-3-(Diphenylamino)-1-phenylprop-2-en-1-one (TE): diphenylamine $(1.01 \mathrm{~g}, 6 \mathrm{mmol})$ was added in a methanol solution of 1-phenylprop-2-yn-1-one ( $0.65 \mathrm{~g}, 5 \mathrm{mmol})$ and the reaction mixture was stirred overnight at room temperature. The solution was then concentrated by rotary evaporation and purified by silica gel column chromatography (petroleum ether/ethyl acetate $=10 / 1, \mathrm{v} / \mathrm{v}$ ) to give TE as a white solid (1.09 g, $4.4 \mathrm{mmol}, 73 \%)$. m.p. 118-120 ${ }^{\circ}$ $\mathrm{C} ;{ }^{1} \mathrm{HNMR}\left(500 \mathrm{MHz}, \mathrm{CDCl}_{3}\right): \delta(\mathrm{ppm}) 8.46(\mathrm{~d}, J=12.8 \mathrm{~Hz}$, $1 \mathrm{H}, \mathrm{C}=\mathrm{CH}), 7.78(\mathrm{~d}, J=8.5 \mathrm{~Hz}, 2 \mathrm{H}, \mathrm{Ar}-\mathrm{H}), 7.41(\mathrm{~m}, 7 \mathrm{H}$, $\mathrm{Ar}-\mathrm{H}), 7.27(\mathrm{~d}, J=7.6 \mathrm{~Hz}, 2 \mathrm{H}, \mathrm{Ar}-\mathrm{H}), 7.19(\mathrm{~d}, J=7.6 \mathrm{~Hz}, 4$ $\mathrm{H}, \mathrm{Ar}-\mathrm{H}), 6.03$ (d, $J=12.8 \mathrm{~Hz}, 1 \mathrm{H}, \mathrm{CH}=\mathrm{C}) ;{ }^{13} \mathrm{C} \mathrm{NMR}$ (125 MHz, $\left.\mathrm{CDCl}_{3}\right): \delta(\mathrm{ppm}) 189.6(\mathrm{C}=0), 148.9(\mathrm{C}=\mathrm{C})$, 139.5, 131.6, 129.8, 128.2, $127.8\left(\mathrm{C}_{\mathrm{Ar}}\right), 100.4(\mathrm{C}=\mathrm{C})$; IR $\left(\mathrm{KBr}, \mathrm{cm}^{-1}\right)$ 3050, 1645, 1531, 1490, 1242, 1048, 700; HRMS (EI) calcd: $m / z=299.1310$, found: $m / z=300.1386$ $[\mathrm{M}+\mathrm{H}]^{+}$; anal. calcd for C21H17NO: C 84.25, H 5.72, N 4.68, found: C 83.71, H 4.61, N 4.61.

1-(4-Bromophenyl)prop-2-yn-1-ol: a solution of ethynylmagnesium bromide $(0.5 \mathrm{M}$ in THF, $195 \mathrm{~mL}$, $97.5 \mathrm{mmol}, 1.3$ equiv.) was added at $0{ }^{\circ} \mathrm{C}$ to a solution of the corresponding 4-bromobenzaldehyde (13.9 g, $75 \mathrm{mmol})$ in THF $(20 \mathrm{~mL})$. After the mixture had been stirred for $2 \mathrm{~h}$ at room temperature, a saturated solution of $\mathrm{NH}_{4} \mathrm{Cl}(100 \mathrm{~mL})$ was added to the solution and the THF was evaporated under vacuum. The aqueous phase was extracted three times with ethyl acetate and the organic layers were washed with water and brine and then dried with anhydrous $\mathrm{Na}_{2} \mathrm{SO}_{4}$. After evaporation of the solvent, the resulting crude product was purified by column chromatography (heptane/ethyl acetate $=20 / 1, \mathrm{v} / \mathrm{v}$ ) to give in pure form a yellow solid (12.5 g, $59 \mathrm{mmol}, 79 \%)$. ${ }^{1} \mathrm{H}$ NMR (400 MHz, $\mathrm{CDCl}_{3}$ ): $\delta(\mathrm{ppm}) 7.52(\mathrm{~d}, J=8.5 \mathrm{~Hz}, 2$ $\mathrm{H}, \mathrm{Ar}-\mathrm{H}), 7.43(\mathrm{~d}, J=8.5 \mathrm{~Hz}, 2 \mathrm{H}, \mathrm{Ar}-\mathrm{H}), 5.43$ (d, $J=2.2 \mathrm{~Hz}, 1 \mathrm{H}, \mathrm{CH}), 2.68(\mathrm{~d}, J=2.2 \mathrm{~Hz}, 1 \mathrm{H}, \mathrm{C} \equiv \mathrm{CH})$, $2.08(\mathrm{~s}, 1 \mathrm{H}, \mathrm{OH}) .{ }^{13} \mathrm{C} \mathrm{NMR}\left(100 \mathrm{MHz}, \mathrm{CDCl}_{3}\right): \delta(\mathrm{ppm})$ 139.0, 131.9, $128.3\left(\mathrm{C}_{\mathrm{Ar}}\right), 82.9,75.2(\mathrm{C} \equiv \mathrm{C}), 63.8(\mathrm{CH})$.

1-(4-Bromophenyl)prop-2-yn-1-one: IBX (30.7 g, $110 \mathrm{mmol}, 2$ equiv.) was added in one portion to a solution of 1-(4-bromophenyl)prop-2-yn-1-ol (11.8 g, $55 \mathrm{mmol})$ in ethyl acetate $(25 \mathrm{~mL})$. The mixture was heated at $90{ }^{\circ} \mathrm{C}$ and stirred overnight. After recooling to room temperature, the mixture was filtered and ethyl acetate was evaporated under vacuum. The resulting crude product was purified by column chromatography (heptane/ethyl acetate $100 / 1, \mathrm{v} / \mathrm{v}$ ) to give in pure form as a yellow solid (10.7 g, $51 \mathrm{mmol}, 92 \%) .{ }^{1} \mathrm{H} \mathrm{NMR}(400 \mathrm{MHz}$, $\left.\mathrm{CDCl}_{3}\right): \delta(\mathrm{ppm}) 8.02(\mathrm{~d}, J=8.7 \mathrm{~Hz}, 2 \mathrm{H}, \mathrm{Ar}-\mathrm{H}), 7.64$ (d, $J=8.7 \mathrm{~Hz}, 2 \mathrm{H}, \mathrm{Ar}-\mathrm{H}), 3.46(\mathrm{~s}, 1 \mathrm{H}, \mathrm{C} \equiv \mathrm{CH}) .{ }^{13} \mathrm{C} \mathrm{NMR}$ $\left(100 \mathrm{MHz}, \mathrm{CDCl}_{3}\right): \delta(\mathrm{ppm}) 176.5(\mathrm{C}=0), 135.1,131.6$, $131.3,130.1\left(\mathrm{C}_{\mathrm{Ar}}\right), 81.3,79.8(\mathrm{C} \equiv \mathrm{C})$.

(E)-1-(4-Bromophenyl)-3-(diphenylamino)prop-2-en1-one (BrTE): diphenylamine $(2.03 \mathrm{~g}, 12 \mathrm{mmol})$ was added in a methanol solution of 1-(4-bromophenyl) prop-2-yn-1-one $(2.09 \mathrm{~g}, 10 \mathrm{mmol})$, and the reaction mixture was stirred overnight at room temperature. The solution was then concentrated by rotary evaporation and purified by silica gel column chromatography (petroleum ether/ethyl acetate $=20 / 1, v / v$ ) to give BrTE as a white solid (2.94, $7.8 \mathrm{mmol}, 78 \%$ ). M.p. 150$152{ }^{\circ} \mathrm{C} ;{ }^{1} \mathrm{H}$ NMR (500 MHz, $\mathrm{CDCl}_{3}$ ): $\delta(\mathrm{ppm}) 8.50(\mathrm{~d}$, $J=12.5 \mathrm{~Hz}, 1 \mathrm{H}, \mathrm{C}=\mathrm{CH}), 7.64(\mathrm{~d}, J=8.5 \mathrm{~Hz}, 2 \mathrm{H}, \mathrm{Ar}-\mathrm{H})$, $7.50(\mathrm{~d}, J=8.5 \mathrm{~Hz}, 2 \mathrm{H}, \mathrm{Ar}-\mathrm{H}), 7.43$ (t, J=7.2 Hz, $4 \mathrm{H}, \mathrm{Ar}-$ H), 7.30 (m, $2 \mathrm{H}, \mathrm{Ar}-\mathrm{H}), 7.19$ (d, $J=7.2 \mathrm{~Hz}, 4 \mathrm{H}, \mathrm{Ar}-\mathrm{H})$, $5.96(\mathrm{~d}, J=12.5 \mathrm{~Hz}, 1 \mathrm{H}, \mathrm{CH}=\mathrm{C}) ;{ }^{13} \mathrm{C} \mathrm{NMR}(125 \mathrm{MHz}$, $\left.\mathrm{CDCl}_{3}\right): \delta(\mathrm{ppm}) 188.3(\mathrm{C}=\mathrm{O}), 149.6(\mathrm{C}=\mathrm{C}), 138.1$, 131.5, 129.9, 129.4, 126.6 $\left(\mathrm{C}_{\mathrm{Ar}}\right), 99.7(\mathrm{C}=\mathrm{C})$; IR $(\mathrm{KBr})$ 3061, 1648, 1538, 1486, 1248, 1052, $705 \mathrm{~cm}^{-1}$; HRMS (EI) calcd: $m / z=377.0415$, found: $m / z=378.0482[\mathrm{M}$ $+\mathrm{H}]^{+}$; anal. calcd for $\mathrm{C}_{21} \mathrm{H}_{16} \mathrm{BrNO}$ : C 66.52, $\mathrm{H} \mathrm{4.29,} \mathrm{N}$ 3.63, found: $\mathrm{C} 66.68, \mathrm{H} 4.26, \mathrm{~N} 3.70$.

(E)-3-(Bis(4-bromophenyl)amino)-1-(4-bromophenyl) prop-2-en-1-one (Br3TE): bis(4-bromophenyl)amine (1.96, $6 \mathrm{mmol}$ ) was added in a methanol solution of 1(4-bromophenyl)prop-2-yn-1-one (1.05 g, $5 \mathrm{mmol}$ ), and the reaction mixture was stirred overnight at room temperature. The solution was then concentrated by rotary evaporation and purified by silica gel column chromatography (petroleum ether/ethyl acetate $=20 / 1$, $\mathrm{v} / \mathrm{v}$ ) to give Br3TE as a white solid (1.55 g, $2.9 \mathrm{mmol}, 58 \%$ ). M.p. $186-188{ }^{\circ} \mathrm{C} ;{ }^{1} \mathrm{H}$ NMR $\left(500 \mathrm{MHz}, \mathrm{CDCl}_{3}\right): \delta(\mathrm{ppm}) 8.30$ $(\mathrm{d}, J=12.8 \mathrm{~Hz}, 1 \mathrm{H}, \mathrm{C}=\mathrm{CH}), 7.65(\mathrm{~d}, J=8.5 \mathrm{~Hz}, 2 \mathrm{H}, \mathrm{Ar}-\mathrm{H})$, 7.60-7.49 (m, $6 \mathrm{H}, \mathrm{Ar}-\mathrm{H}), 7.04$ (d, $J=8.5 \mathrm{~Hz}, 4 \mathrm{H}, \mathrm{Ar}-\mathrm{H})$, $6.00(\mathrm{~d}, J=12.8 \mathrm{~Hz}, 1 \mathrm{H}, \mathrm{CH}=\mathrm{C}) ;{ }^{13} \mathrm{C}$ NMR $(125 \mathrm{MHz}$, $\left.\mathrm{CDCl}_{3}\right): \delta(\mathrm{ppm}) 188.3(\mathrm{C}=\mathrm{O}), 148.1(\mathrm{C}=\mathrm{C}), 137.9,133.4$, 131.6, 129.3, $126.9\left(\mathrm{C}_{\mathrm{Ar}}\right), 100.9(\mathrm{C}=\mathrm{C})$; IR ( $\left.\mathrm{KBr}\right) 3048$, 1641, 1542, 1487, 1251, $804 \mathrm{~cm}^{-1}$; HRMS (EI) calcd: $m /$ $z=534.8626$, found: $m / z=535.8677[\mathrm{M}+\mathrm{H}]^{+}$; anal. calcd for C21H14Br3NO: C 66.52, H 4.29, N 3.63, found: C $66.68, \mathrm{H} 4.26$, N 3.70 .

\section{Funding Information}

This work was financially supported by the Strategic Priority Research Program of the Chinese Academy of Sciences (Grant No. XDB12010200) and the National Natural Science 
Foundation of China (Grant Nos. 51833009, 21674111, 21574131, 51973211, and 21322403).

\section{Supporting Information}

Supporting information for this article is available online at https://doi.org/10.1055/s-0040-1701249.

\section{References}

(1) (a) Chen, C.-T. Chem. Mater. 2004, 16, 4389. (b) Ding, D.; Li, K.; Liu, B.; Tang, B. Z. Acc. Chem. Res. 2013, 46, 2441. (c) Luo, D.; Xiao, P.; Liu, B. Chem. Rec. 2019, 19, 1596. (d) Sedgwick, A. C.; Wu, L.; Han, H. H.; Bull, S. D.; He, X. P.; James, T. D.; Sessler, J. L.; Tang, B. Z.; Tian, H.; Yoon, J. Chem. Soc. Rev. 2018, 47, 8842.

(2) (a) Li, Q.; Li, Z. Adv. Sci. 2017, 4, 1600484. (b) Mei, J.; Leung, N. L.; Kwok, R. T.; Lam, J. W.; Tang, B. Z. Chem. Rev. 2015, 115, 11718. (c) Naito, H.; Morisaki, Y.; Chujo, Y. Angew. Chem. Int. Ed. 2015, $54,5084$.

(3) Luo, J.; Xie, Z.; Lam, J. W.; Cheng, L.; Chen, H.; Qiu, C.; Kwok, H. S.; Zhan, X.; Liu, Y.; Zhu, D.; Tang, B. Z. Chem. Commun. 2001, 1740.

(4) (a) Yuan, W. Z.; Tan, Y.; Gong, Y.; Lu, P.; Lam, J. W.; Shen, X. Y.; Feng, C.; Sung, H. H.; Lu, Y.; Williams, I. D.; Sun, J. Z.; Zhang, Y.; Tang, B. Z. Adv. Mater. 2013, 25, 2837. (b) Cai, S.; Shi, H.; Tian, D.; Ma, H.; Cheng, Z.; Wu, Q.; Gu, M.; Huang, L.; An, Z.; Peng, Q.; Huang, W. Adv. Funct. Mater. 2018, 28, 1705045.

(5) (a) Yu, T.; Ou, D.; Yang, Z.; Huang, Q.; Mao, Z.; Chen, J.; Zhang, Y.; Liu, S.; Xu, J.; Bryce, M. R.; Chi, Z. Chem. Sci. 2017, 8, 1163. (b) Xia, G.; Jiang, Z.; Shen, S.; Liang, K.; Shao, Q.; Cong, Z.; Wang, H. Adv. Opt. Mater. 2019, 7, 1801549.

(6) Sagara, Y.; Kato, T. Angew. Chem. Int. Ed. 2008, 47, 5175.

(7) Song, X.; Zhang, Z.; Zhang, S.; Wei, J.; Ye, K.; Liu, Y.; Marder, T. B.; Wang, Y. J. Phys. Chem. Lett. 2017, 8, 3711.

(8) (a) Xu, B.; Li, W.; He, J.; Wu, S.; Zhu, Q.; Yang, Z.; Wu, Y. C.; Zhang, Y.; Jin, C.; Lu, P. Y.; Chi, Z.; Liu, S.; Xu, J.; Bryce, M. R. Chem. Sci. 2016, 7, 5307. (b) He, Z.; Zhang, L.; Mei, J.; Zhang, T.; Lam, J. W. Y.; Shuai, Z.; Dong, Y. Q.; Tang, B. Z. Chem. Mater. 2015, 27, 6601. (c) Wu, Q.; Ma, H.; Ling, K.; Gan, N.; Cheng, Z.; Gu, L.; Cai, S.; An, Z.; Shi, H.; Huang, W. ACS Appl. Mater. Interfaces 2018, 10, 33730. (d) Zhang, Y.; Feng, Y.-Q.; Tian, X.-X.; Wang, J.-H.; Li, H.; Han, G.; Li, D. Adv. Opt. Mater. 2018, 6, 1800903.

(9) (a) Desiraju, G. R.; Ho, P. S.; Kloo, L.; Legon, A. C.; Marquardt, R.; Metrangolo, P.; Politzer, P.; Resnati, G.; Rissanen, K.Pure. Appl.Chem.
2013, 85, 1711. (b) Cavallo, G.; Metrangolo, P.; Milani, R.; Pilati, T.; Priimagi, A.; Resnati, G.; Terraneo, G. Chem. Rev. 2016, 116, 2478.

(10) Wang, C.; Danovich, D.; Mo, Y.; Shaik, S. J. Chem. Theory Comput. 2014, 10, 3726.

(11) (a) Christopherson, J. C.; Topić, F.; Barrett, C. J.; Friščić, T. Cryst. Growth Des. 2018, 18, 1245. (b) Tepper, R.; Schubert, U. S. Angew. Chem. Int. Ed. 2018, 57, 6004.

(12) (a) Bunchuay, T.; Docker, A.; Martinez-Martinez, A. J.; Beer, P. D. Angew. Chem. Int. Ed. 2019, 58, 13823. (b) Gropp, C.; Husch, T.; Trapp, N.; Reiher, M.; Diederich, F. J. Am. Chem. Soc. 2017, 139, 12190. (c) Gropp, C.; Quigley, B. L.; Diederich, F.J. Am. Chem. Soc. 2018, 140, 2705.

(13) Bulfield, D.; Huber, S. M. Chem. Eur. J. 2016, 22, 14434.

(14) (a) Ang, S. J.; Chwee, T. S.; Wong, M. W. J. Phys. Chem. C. 2018, 122, 12441. (b) Wang, J.; Wang, C.; Gong, Y.; Liao, Q.; Han, M.; Jiang, T.; Dang, Q.; Li, Y.; Li, Q.; Li, Z. Angew. Chem. Int. Ed. 2018, 57, 16821. (c) Kanosue, K.; Ando, S. ACS Macro Lett. 2016, 5, 1301.

(15) (a) Kenry, Chen, C.; Liu, B. Nat. Commun. 2019, 10, 2111. (b) Lucenti, E.; Forni, A.; Botta, C.; Giannini, C.; Malpicci, D.; Marinotto, D.; Previtali, A.; Righetto, S.; Cariati, E. Chem. Eur. J. 2019, 25, 2452. (c) Wang, J.; Wang, C.; Gong, Y.; Liao, Q.; Han, M.; Jiang, T.; Dang, Q.; Li, Y.; Li, Q.; Li, Z. Angew. Chem. Int. Ed. 2018, 57, 16821. (d) Bolton, O.; Lee, K.; Kim, H. J.; Lin, K. Y.; Kim, J. Nat. Chem. 2011, 3, 205.

(16) (a) Chen, W.; Zhang, S.; Dai, G.; Chen, Y.; Li, M.; Zhao, X.; Chen, Y.; Chen, L. Chem. Eur. J. 2019, 25, 469. (b) D’Aléo, A.; Saul, A.; Attaccalite, C.; Fages, F. Mater. Chem. Front. 2019, 3, 86. (c) DeRosa, C. A.; Kerr, C.; Fan, Z.; Kolpaczynska, M.; Mathew, A. S.; Evans, R. E.; Zhang, G.; Fraser, C. L.ACS Appl. Mater.Interfaces 2015, 7, 23633.(d) Shi, H.; An,Z.; Li, P.-Z.; Yin,J.; Xing, G.; He, T.; Chen, H.; Wang,J.; Sun, H.; Huang, W.; Zhao, Y.Cryst. Growth Des. 2016, 16, 808. (e) Yan, D.; Delori, A.; Lloyd, G. O.; Friscic, T.; Day, G. M.; Jones, W.; Lu, J.; Wei, M.; Evans, D. G.; Duan, X. Angew. Chem. Int. Ed. 2011, 50, 12483. (f) Salunke, J. K.; Durandin, N. A.; Ruoko, T. P.; Candeias, N. R.; Vivo, P.; Vuorimaa-Laukkanen, E.; Laaksonen, T.; Priimagi, A.Sci. Rep. 2018, $8,14431$.

(17) Li, H.; Shu, H.; Liu, Y.; Wu, X.; Tian, H.; Tong, H.; Wang, L. Adv. Opt. Mater. 2019, 7, 1801719.

(18) (a) Chisholm, D. R.; Valentine, R.; Pohl, E.; Whiting, A. J. Org. Chem. 2016, 81, 7557. (b) Chassaing, S.; Kueny-Stotz, M.; Isorez, G.; Brouillard, R. Eur. J. Org. Chem. 2007, 15, 2438.

(19) (a) Sasaki, S.; Drummen, G. P. C.; Konishi, G.-I. J. Mater. Chem. C 2016, 4, 2731. (b) Zbigniew, R.; Grabowski, K. R. Chem. Rev. 2003, 103, 3899.

(20) Isayama, K.; Aizawa, N.; Kim, J. Y.; Yasuda, T. Angew. Chem. Int. Ed. 2018, 57, 11982. 